\title{
PENINGKATAN HASIL BELAJAR LARI \\ MELALUI PENERAPAN PROJECT BASED LEARNING SISWA KELAS IV DI SEKOLAH DASAR
}

\author{
Gaguk Iriana \\ Sekolah Dasar Negeri Sentul 3 Kota Blitar \\ Email: Sdnsentultiga@ymail.com
}

\begin{abstract}
The Improvement of the Results of Run Learning through the Implementation of Project Based Learning Grade IV in Elementary School. The problems found in the process of learning indicates that students understand the material being taught. The purpose of this research was to prove whether the application of the model of Learning Project Based Learning can improve learning outcomes basic motion run on elementary school students. The study used is the class action Research (School Action Research). Data analyzed by looking at the percentage of the increase that occurred from cycle to cycle. The results showed the applicability of Project Based Learning can improve student learning outcomes.
\end{abstract}

Keyword: project based learning, improve learning results, run

\begin{abstract}
Abstrak: Peningkatan Hasil Belajar Lari melalui Penerapan Project Based Learning Siswa Kelas IV di Sekolah Dasar. Permasalahan yang ditemukan dalam proses pembelajaran menunjukkan bahwa siswa kurang memahami materi yang diajarkan. Tujuan penelitian ini untuk membuktikan apakah penerapan model pembelajaran project based learning dapat meningkatkan hasil belajar gerak dasar lari pada siswa Sekolah Dasar. Penelitian yang digunakan adalah penelitian tindakan kelas (classroom action research). Data dianalisis dengan melihat persentase peningkatan yang terjadi dari siklus ke siklus. Hasil penelitian menunjukkan penerapan project based learning dapat meningkatkan hasil belajar siswa.
\end{abstract}

Kata kunci: project based learning, meningkatkan hasil belajar, lari

Pembelajaran pada sekolah dasar seringkali mengalami banyak permasalahan, diantaranya tidak tercapai tujuan pembelajaran yang diharapkan secara optimal. Hasil observasi awal pada pembelajaran muatan Pendidikan Jasmani Olahraga dan Kesehatan (PJOK), dijumpai aktivitas yang terjadi di kelas: (1) guru menggunakan model pembelajaran dengan cara ceramah yang cenderung hanya transfer informasi tanpa melibatkan keaktifan siswa; (2) siswa lebih cenderung pasif yang terlihat dari 28 siswa, kurang dari 50\% siswa yang terlihat bersungguh-sungguh dalam belajar, sedangkan siswa yang lain terlihat bergurau dan bosan dengan pembelajaran yang sedang berlangsung; (3) siswa masih takut dan ragu untuk melakukan gerakan jalan, lari lempar dan lompat ataupun mengajukan pertanyaan; (4) rendahnya sikap komunikatif dan sikap saling kerjasama antar siswa selama proses pembelajaran berlangsung.

Berdasarkan hasil observasi yang telah dilakukan diketahui bahwa pembelajaran yang dilakukan masih jauh dari tujuan pendidikan nasional. Undang-undang Nomor 20 Tahun 2003 tentang Sistem Pendidikan Nasional menjelaskan bahwa pengertian pendidikan adalah usaha sadar dan terencana yang tertuang ke dalam tujuan pendidikan nasional dan pendidikan sekolah dasar yaitu, untuk mewujudkan suasana belajar dan 
proses kegiatan pembelajaran dengan tujuan agar siswa secara aktif mengembangkan potensi dirinya untuk memiliki kekuatan spiritual keagamaan, pengendalian diri, kepribadian, kecerdasan, akhlak mulia,serta keterampilan yang diperlukan dirinya dan masyarakat dalam berbangsa dan bernegara. Maka dari itu pembelajaran harus sebanyak mungkin melibatkan siswa agar mampu bereksplorasi dengan menggali berbagai potensi dalam diri siswa sehingga siswa merasa memiliki motivasi untuk belajar, yang akan berdampak pada perolehan hasil belajar siswa.

Aktivitas yang berlangsung di lapangan pada saat melakukan observasi berdampak pada rendahnya motivasi siswa untuk belajar, rendahnya tingkat keaktifan siswa, serta rendahnya interaksi antar siswa untuk bekerja sama sehingga menyebabkan siswa merasa bosan dan pasif pada saat proses pembelajaran yang akhirnya menyebabkan tujuan pembelajaran dan hasil belajar siswa tidak dapat tercapai secara optimal. Hal ini terlihat ketika guru membahas bersama tentang tugas yang telah diberikan terdapat beberapa hasil pekerjaan siswa yang belum bisa dilakukan karena siswa kurang memahami materi yang disampaikan guru.

Permasalahan tersebut terjadi karena guru lebih banyak menggunakan model pembelajaran ceramah dalam pembelajaran serta cenderung hanya membaca buku referensi dan selanjutnya siswa melakukan gerakan dari tugas yang diberikan guru secara individu. Oleh sebab itu, diperlukan adanya kreatifitas guru agar memiliki keahlian untuk memilih dan menggunakan strategi pembelajaran yang sesuai agar pembelajaran bersifat menyenangkan dan siswa mampu bersikap aktif sehingga keberhasilan dalam belajar dapat tercapai secara optimal. Menurut Mulyasa (2007), guru perlu memperhatikan beberapa hal untuk mendukung siswa mencapai keberhasilan belajar, yaitu: (1) mengurangi metode ceramah; (2) bahan harus dimodifikasi dan diperkaya; (3) menggunakan prosedur yang bervariasi; (4) menciptakan situasi belajar yang dapat mengembangkan kemampuan anak untuk bergerak dan bekerja sama; (5) melibatkan siswa dalam berbagai kegiatan.

Menurut Soekamto dkk, (dalam Kuntjojo, dkk 2011:1) model pembelajaran adalah kerangka konseptual yang melukiskan prosedur yang sistematis dalam mengorganisasikan pengalaman belajar untuk mencapai tujuan belajar tertentu, dan berfungsi sebagai pedoman bagi para perancang pembelajaran dan para pengajar dalam merencanakan aktivitas belajar mengajar.

Model pembelajaran project based learning (PBL) adalah salah satu model pembelajaran eksploratif. Model pembelajaran berbasis proyek (project based learning) adalah sebuah model pembelajaran yang menggunakan proyek (kegiatan) sebagai inti pembelajaran. Dalam kegiatan ini, siswa melakukan eksplorasi, penilaian, interpretasi, dan sintesis informasi untuk memperoleh berbagai hasil belajar (pengetahuan, keterampilan, dan sikap). (Faiq, 2014:1).

Pelaksanaan model pembelajaran berbasis proyek memiliki langkah-langkah (sintaks) yang menjadi ciri khasnya dan membedakannya dari model pembelajaran lain seperti model pembelajaran penemuan (discovery learning model) dan model pembelajaran berdasarkan masalah (problem based learning model). Adapun langkah-langkah pembelajaran tersebut adalah: (1) menentukan pertanyaan dasar; (2) membuat desain proyek; (3) menyusun penjadwalan; (4) memonitor kemajuan proyek; (5) penilaian hasil; (6) evaluasi pengalaman.

Penelitianinibertujuanuntukmendeskripsikan penerapan pembelajaran $\mathrm{PBL}$, mengetahui respon siswa tentang pembelajaran yang menggunakan PBL dan apakah penerapan model pembelajaran PBL dapat meningkatkan hasil belajar siswa pada mata pelajaran PJOK khususnya dalam materi lari.

Penelitian ini diharapkan dapat memberikan alternatif cara mengajar kepada guru untuk memperbaiki kinerja guru, memperkaya variasi dalam memberikan materi pelajaran, serta meningkatkan kemampuannya dalam menggunakan berbagai model pembelajaran khususnya model pembelajaran PBL sebagai upaya dalam meningkatkan profesionalisme guru.

Sedangkan bagi peneliti, penerapan model pembelajaran PBL dijadikan sebagai sarana untuk mempraktikkan teori-teori yang diperoleh selama bertugas dan hasil melaksanakan atau mengikuti pengembangan diri dengan kenyataan di sekolah. Melatih kreativitas dalam merancang pembelajaran yang menarik dan melatih kemampuan mengatasi permasalahan yang muncul di kelas. 
Melalui model pembelajaran PBL pada muatan PJOK dapat memberikan pengalaman belajar yang bervariasi sehingga dapat meningkatkan hasil belajar siswa, menambah motivasi belajar siswa, meningkatkan keaktifan siswa dalam belajar, memupuk rasa tanggung jawab dan kerjasama antar siswa. Selain itu dapat memberikan landasan kebijakan yang akan diambil dalam meningkatkan mutu hasil belajar siswa serta memberikan masukan pada pihak sekolah dalam hal peningkatan proses pembelajaran pada setiap pembelajaran dengan adanya model pembelajaran PBL.

\section{METODE}

Penelitian ini dilaksanakan pada siswa Kelas IV/A di Sekolah Dasar Negeri Sentul 3 Kota Blitar pada Semester II Tahun Pelajaran $2015 / 2016$. Subjek penelitian ini adalah siswa kelas IV /A dengan jumlah siswa sebanyak 28 siswa, terdiri dari 16 siswa laki-laki dan 12 siswa perempuan. Penelitian ini berbentuk Penelitian Tindakan Sekolah (Classroom Action Research) yang dapat diartikan bahwa yang dimaksud dengan PTK adalah pencermatan terhadap kegiatan belajar berupa sebuah tindakan, yang sengaja dimunculkan dan terjadi dalam sebuah kelas secara bersamaan.

Pendekatan yang digunakan pada penelitian ini pendekatan deskriptif kualitatif yaitu penelitian yang menggambarkan bagaimana suatu model pembelajaran diterapkan dan bagaimana hasil yang diharapkan dapat tercapai. Penelitian kualitatif adalah penelitian yang menggunakan latar alamiah, dengan maksud menafsirkan fenomena yang terjadi dan dilakukan dengan jalan melibatkan berbagai metode yang ada (Denzin dan Lincoln dalam Moleong, 2004:5). Penelitian ini menggunakan bentuk penelitian tindakan kolaboratif, dimana peneliti bertindak sebagai guru sedangkan wali kelas IV sebagai pengamat (observer).

Penelitian ini menggunakan model penelitian tindakan sekolah yang dikembangkan oleh Kemmis dan Taggart (1998) yang berlangsung selama dua siklus. Masing-masing siklus terdiri dari tahapan perencanaan, pelaksanaan, observasi, dan refleksi. Tahap perencanaan kegiatan yang dilakukan peneliti adalah menyusun rancangan untuk menentukan langkah-langkah yang akan dilakukan dalam tindakan. Tahap pelaksanaan tindakan penelitian menjelaskan mengenai langkah-langkah kegiatan yang harus dilakukan oleh guru dan siswa untuk meningkatkan hasil belajar. Kegiatan pelaksanaan tindakan diawali dengan tahap pra tindakan yang meliputi pengamatan dan refleksi, kemudian dilanjutkan dengan tahap tindakan yang terdiri dari dua siklus. Pengamatan atau observasi adalah proses pengumpulan data, peneliti melakukan pengamatan dan mencatat semua hal yang terjadi selama pelaksanaan kegiatan berlangsung untuk memperoleh data yang akurat untuk perbaikan siklus selanjutnya. Pada tahap refleksi, peneliti melakukan evaluasi terhadap apa yang telah dilakukan.

Teknik pengumpulan data dalam penelitian ini adalah dengan menggunakan teknik observasi, teknik dokumentasi, dan tes . Alat yang digunakan dalam teknik observasi yaitu lembar observasi. Dokumentasi yang digunakan pada penelitian ini adalah foto. Tes dalam penelitian ini menggunakan tes praktik yaitu lari $40 \mathrm{~m}$ secara individu.

Analisis data dilakukan setelah pelaksanaan tindakan setiap siklus. Teknik analisis data yang digunakan dalam penelitian ini adalah teknik analisis data deskriptif kualitatif, yaitu reduksi data, penyajian data, dan penarikan kesimpulan.

Reduksi data adalah proses menyeleksi data yang sudah terkumpul, memfokuskan dan menyederhanakan data sampai penyusunan data. Penyajian data dilakukan dengan menyusun dalam bentuk tabel dan narasi, lalu dibandingkan dan dipadukan dengan berbagai informasi atau data yang diperoleh dari hasil reduksi data hingga memberi kemungkinan adanya penarikan kesimpulan dan pengambilan tindakan. Penarikan kesimpulan adalah pengambilan inti dari data-data yang telah dikumpulkan. Penarikan kesimpulan dilihat dari hasil ketuntasan siswa baik secara individu maupun klasikal selama pembelajaran

\section{HASIL DAN PEMBAHASAN}

\section{Hasil}

Keadaan awal sebelum penerapan PBL diketahui bahwa guru dalam mengajar lebih banyak menggunakan metode ceramah yang tidak dapat menarik perhatian siswa untuk mengikuti proses pembelajaran. Kegiatan pembelajaran lebih 
berpusat pada guru dan tidak melibatkan siswa secara langsung. Hal ini dapat diketahui bahwa dari 28 siswa hanya 5 siswa yang tuntas belajar (18\%) dan siswa yang belum tuntas belajar 23 siswa (82\%) yang masih mendapatkan nilai dibawah Kriteria Ketuntasan Minimum (KKM).

\section{Hasil Siklus I}

Penilaian aktivitas guru dengan menerapkan model pembelajaran PBL menggunakan lembar observasi guru. Hasil observasi pada siklus I, peneliti mendapatkan nilai persentase rata-rata sebesar 91\%, yakni termasuk ke dalam kriteria sangat baik (A).

Berdasarkan hasil observasi, guru sudah membuka pembelajaran dengan baik. Guru perlu meningkatkan kegiatan untuk memantau kedisiplinan siswa dan keterampilan dalam mengkondisikan kelas. Motivasi yang diberikan guru kepada siswa ketika proses pembelajaran dengan menggunakan model pembelajaran PBL dapat meningkatkan semangat siswa dalam belajar. Kegiatan diskusi kelompok sudah meningkat, terlihat dalam diskusi tidak ada siswa yang masih sibuk bermain sendiri. Siswa terlihat lebih antusias sehingga proses pembelajaran berjalan lebih menyenangkan.
Berdasarkan hasil observasi dan analisis data serta data pendukung pada siklus I pertemuan 1 dan pertemuan 2 maka refleksi pada siklus I adalah sebagai berikut: (1) langkah-langkah pembelajaran yang dilaksankan guru dengan menggunakan model PBL sudah mengalami peningkatan dari pertemuan 1 ke pertemuan 2, yaitu pada pertemuan 1 sebesar $75 \%$ dan meningkat menjadi $91 \%$. Pada pertemuan 2, namun guru masih perlu meningkatkan hasil yang diperoleh untuk aspek yang belum nampak; (2) hasil belajar siswa pada siklus I menunjukkan peningkatan yaitu nilai akhir rata-rata kelas pada pada siklus I pertemuan 1 yakni 65,9 dan pada siklus I pertemuan 2 meningkat menjadi 72,2 , sedangkan persentase ketuntasan belajar siswa yaitu $25 \%$ siswa yang tuntas belajar dan $75 \%$ tidak tuntas belajar; (3) aktivitas siswa selama proses pembelajaran dengan menggunakan model pembelajaran PBL sudah menunjukkan peningkatan dari pertemuan 1 ke pertemuan 2 ,tetapi masih ada beberapa aspek yang belum. Nampak diantaranya siswa belum berani untuk menyampaikan pendapat terhadap jawaban kelompok lain, siswa masih ragu dan kurang berani untuk menyampaikan kesan atau pendapat mengenai pembelajaran. Hasil refleksi dari siklus I ini kemudian digunakan untuk melaksanakan perbaikan pembelajaran pada siklus II.

Tabel 1 Hasil Observasi Siklus I

\begin{tabular}{clccc}
\hline No & Aspek Aktivitas & Pertemuan I & Pertemuan II & Rerata \\
\hline 1 & Aktivitas guru & $75 \%$ & $91 \%$ & $83 \%$ \\
2 & Aktivitas siswa & $75 \%$ & $91 \%$ & $83 \%$ \\
\hline & Kriteria & Baik & Sangat Baik & Baik \\
\hline
\end{tabular}

Tabel 2 Hasil Observasi Siklus II

\begin{tabular}{clccc}
\hline No & Aspek Aktivitas & Pertemuan I & Pertemuan II & Rerata \\
\hline 1 & Aktivitas guru & $94 \%$ & $97 \%$ & $95,5 \%$ \\
2 & Aktivitas siswa & $94 \%$ & $97 \%$ & $95,5 \%$ \\
\hline & Kriteria & Sangat Baik & Sangat Baik & Sangat Baik \\
\hline
\end{tabular}


Tabel 3 Peningkatan Hasil Belajar Siswa melalui Model Pembelajaran PBL

\begin{tabular}{llcccccc}
\hline \multirow{2}{*}{ No } & Hasil belajar & \multicolumn{2}{c}{ Pratindakan } & \multicolumn{2}{c}{ Siklus I } & \multicolumn{2}{c}{ Siklus II } \\
\cline { 3 - 8 } & Tuntas & $\begin{array}{c}\text { Tidak } \\
\text { Tuntas }\end{array}$ & Tuntas & $\begin{array}{c}\text { Tidak } \\
\text { Tuntas }\end{array}$ & Tuntas & $\begin{array}{c}\text { Tidak } \\
\text { Tuntas }\end{array}$ \\
\hline 1. & Jumlah siswa & 5 & 23 & 7 & 21 & 26 & 2 \\
2. & Presentase & $18 \%$ & $82 \%$ & $25 \%$ & $75 \%$ & $93 \%$ & $7 \%$ \\
\hline
\end{tabular}

\section{Hasil Siklus II}

Berdasarkan hasil observasi, analisis data serta data pendukung pada siklus II pertemuan 1 dan pertemuan 2, refleksi yang dilakukan sebagai berikut: (1) aktivitas guru mengenai langkahlangkah pembelajaran menggunakan model PBL sudah mengalami peningkatan yaitu pada pertemuan 1 sebesar $94 \%$ dan meningkat menjadi $97 \%$ pada pertemuan 2 , sehingga hasil yang diperoleh guru sudah mendapatkan nilai yang sangat baik; (2) hasil belajar siswa pada siklus II pertemuan 2 menunjukkan nilai akhir rata-rata kelas. Pada siklus II pertemuan 1 yakni 77,9 dan pada siklus II pertemuan 2 meningkat menjadi 94,4. Sedangkan persentase ketuntasan belajar siswa yaitu $93 \%$ siswa yang tuntas belajar dan $7 \%$ tidak tuntas belajar; (3) aktivitas siswa dalam proses pembelajaran PBL sudah menunujukkan peningkatan. Sehingga pada siklus II pertemuan 2 semua aspek dalam aktivitas siswa sudah tampak, tidak ada siswa yang ramai sendiri, siswa sudah berani untuk bertanya jawab dengan guru atau menyampaikan kesan maupun pendapat.

Peningkatan hasil belajar siswa memberikan gambaran adanya perhatian dan pemahaman siswa terhadap pembelajaran. Dampak dari adanya perhatian dan pemahaman siswa terhadap pembelajaran juga ditunjukan dengan adanya peningkatan ketuntasan belajar secara umum. Peningkatan tersebut dapat dilihat pada Tabel 3.

Tabel 3 menunjukan perbandingan rata-rata nilai hasil belajar siswa mulai dari pratindakan, siklus I dan siklus II. Pada pra tindakan, siswa yang tuntas hanya mencapai 5 siswa $(18 \%)$, sedangkan yang belum tuntas 23 siswa (82\%). Pada siklus I hasil belajar siswa mengalami peningkatan setelah diterapkannya model pembelajaran PBL yakni siswa yang tuntas belajar mencapai rata-rata 7 siswa $(25 \%)$, sedangkan yang belum tuntas 21 siswa (75\%). Pada siklus II hasil belajar siswa melalui penerapan model pembelajaran PBL meningkat kembali yakni siswa yang tuntas belajar mencapai 26 siswa (93\%) sedangkan yang belum tuntas 2 siswa (7\%).

\section{Pembahasan}

Berdasarkan observasi, model pembelajaran PBL telah dilaksanakan sesuai dengan langkahlangkah pada rencana pelaksanaan pembelajaran. Temuan aktivitas guru pada pelaksanaan tindakan siklus I yaitu guru telah melaksanakan pembelajaran dengan cukup baik, salah satunya adalah guru menjelaskan kegiatan pembelajaran yang akan dilakukan. Guru juga memberikan motivasi kepada siswa agar selalu bersemangat dalam belajar. Hal ini dilakukan untuk menyiapkan dan membimbing siswa agar terlibat aktif dalam pembelajaran, dan siswa memiliki motivasi dalam diri mereka untuk belajar, sehingga keberhasilan dalam belajar dapat tercapai. Dimyati dan Mudjiono (2002:43) menjelaskan bahwa motivasi merupakan faktor seperti halnya intelegensi dan hasil belajar sebelumnya yang dapat menentukan keberhasilan belajar siswa dalam bidang pengetahuan, nilai-nilai dan keterampilan. Berdasarkan pendapat tersebut motivasi serta penjelasan guru mengenai kegiatan pembelajaran mata pelajaran PJOK melalui model PBL yang akan dilaksanakan sangatlah penting bagi siswa agar siswa jelas dengan kegiatan yang direncanakan oleh guru.

Pembelajaran yang dilaksanakan pada siklus I dan siklus II sesuai dengan RPP yang telah disusun. Secara garis besar, pembelajaran pada siklus I dan siklus II dapat diringkas yaitu: (1) guru memberikan penjelasan tentang materi dan memberikan contoh teknik lari; (2) siswa membentuk kelompok asli dan diberi tugas menyelesaikan tugas sesuai dengan nomor anggota yang diterimanya; (3) siswa membentuk kelompok baru, berdiskusi untuk menyelesaikan tugas yang 
diterima; (4) siswa kembali ke kelompok asli masing-masing untuk bergantian menjelaskan jawaban serta cara penyelesaian dari tugas yang telah di diskusikan dengan kelompok sebelumnya; dan (5) siswa menyelesaikan tes atau evaluasi di akhir kegiatan secara individu.

Pada perencanaan siklus I peneliti: (1) memilih materi untuk yang akan dipelajari siswa; (2) merancang Rencana Pelaksanaan Pembelajaran (RPP) dengan model pembelajaran PBL; (3) menyiapkan media pembelajaran dan contoh soal beserta penyelesaiannya; (4) menyiapkan alat atau instrumen pengumpul data yang akan digunakan untuk pengumpulan data berupa lembar observasi kemampuan guru selama proses pembelajaran dengan menggunakan model pembelajaran PBL, lembar kerja siswa (LKS), butir soal dan jawaban tes individu, lembar observasi siswa selama proses pembelajaran, lembar catatan lapangan, serta kamera untuk keperluan dokumentasi berupa foto saat kegiatan pembelajaran.

Siklus I pertemuan 1 dilaksanakan pada tanggal 24 Maret 2016 sedangkan pertemuan 2 dilaksanakan pada tanggal 31 Maret 2016 selama 4x35 menit. Kegiatan diawali dengan salam, presensi, apersepsi, menyampaikan informasi materi yang akan dilaksanakan, dan tujuan dari kegiatan yang akan dilaksanakan. Selanjutnya pada kegiatan inti guru membagi siswa menjadi 4 kelompok dengan anggota 7 siswa dalam setiap kelompok. Setelah itu guru memberikan contoh cara melakukan gerakan teknik dasar lari dengan materi yang diajarkan, kemudian guru memberikan kesempatan siswa untuk bertanya mengenai contoh cara melakukan gerakan teknik dasar lari yang diberikan, tetapi tidak ada siswa yang bertanya.

Pada kegiatan selanjutnya guru membagikan nomor anggota kepada setiap kelompok. Guru menjelaskan cara melakukan gerakan teknik dasar lari untuk setiap siswa, yakni setiap siswa mendapat kesempatan lari sesuai dengan nomor anggota yang diterimanya. Setelah itu disusul nomor anggota yang lain secara berurutan. Kemudian, pada kegiatan selanjutnya guru meminta siswa dalam kelompok asli untuk saling berpisah dan bergabung dengan siswa yang memiliki nomor anggota kelompok yang sama. Setiap kelompok baru dipersilahkan berdiskusi mengenai gerakan teknik dasar lari yang telah diberikan.
Tahap selanjutnya guru meminta siswa kembali ke kelompok asli setelah selesai berdiskusi dengan kelompok yang baru tadi. Kemudian, guru meminta siswa untuk bergantian menjelaskan mengenai gerakan teknik dasar lari yang diberikan dan yang telah diselesaikannya kepada kelompok asli, serta memastikan bahwa semua anggota kelompok asli mengerti mengenai gerakan teknik dasar lari yang telah diselesaikan oleh kelompok baru tadi. Siswa terlihat cukup antusias dengan kegiatan kelompok yang dilakukan.

Pada saat kegiatan inti ini berlangsung guru juga memberikan penguatan kepada siswa serta melakukan penilaian terhadap aktivitas siswa dengan menggunakan lembar observasi dan penilaian afektif. Tahap selanjutnya adalah guru memberikan tes individu pada siswa. Guru memberikan petunjuk mengenai cara tes lari dan guru meminta siswa untuk mempraktikan tes yang diberikan secara individu.

Pada kegiatan akhir, yang dilakukan guru adalah merefleksi kegiatan serta bertanya jawab dengan siswa. Guru bertanya kepada siswa apakah ada yang belum dimengerti mengenai kegiatan pembelajaran yang telah dilakukan dan bagaimana perasaan siswa setelah melakukan kegiatan pembelajaran dengan menggunakan model PBL. Selanjutnya guru mengajak siswa untuk melaksanakan doa dan guru mengucapkan salam penutup.

Penerapan model pembelajaran PBL pada mata pelajaran PJOK materi lari pada siklus I sudah berjalan dengan lancar. Guru sudah cukup baik dalam pelaksanaan pembelajaran sesuai dengan RPP yang telah dibuat sebelumnya. Namun masih ada beberapa langkah pembelajaran yang belum dilaksanakan.

Sedangkan dari aktivitas pembelajaran siswa pada siklus I, keaktifan siswa dalam pembelajaran sudah mulai muncul. Hal ini menunjukkan bahwa siswa telah menunjukkan aktivitas yang positif pada siklus I ketika diterapkan model pembelajaran PBL. Hasil belajar siswa dalam pelaksanaan siklus I diketahui bahwa, masih cukup banyak siswa yang belum mencapai KKM yang ditentukan. Namun dalam hal ini sudah mengalami peningkatan jika dibandingkan dengan pra tindakan.

Perencanaan pada siklus II, pertemuan disusun berdasarkan hasil dari refleksi pada kegiatan siklus I. Tahap ini diawali dengan perbaikan 
dan penyusunan RPP yang akan dilaksanakan berdasarkan refleksi siklus I. Pada perencanaan siklus II peneliti tetap menggunakan model pembelajaran PBL untuk mengatasi masalah yang muncul pada kegiatan siklus I.

Siklus II pertemuan 1 dilaksanakan pada tanggal 07 April 2016 selama 4x35 menit. Kegiatan pada siklus II pertemuan 1 seperti halnya pada siklus I dengan menggunakan materi yang telah dipilih yakni teknik gerakan tangan dalam lari. Siklus II pertemuan 2 dilaksanakan pada tanggal 14 April 2016 selama 4x35 menit dengan menggunakan materi teknik gerakan gabungan tungkai dengan tangan dalam lari dengan baik dan benar.

Hasil observasi aktivitas guru menggunakan lembar observasi guru. Hasil observasi pada siklus II, peneliti mendapatkan nilai persentase rata-rata sebesar 95,5\%, yakni termasuk ke dalam kriteria sangat baik (A). Dari hasil observasi, guru sudah membuka pembelajaran dengan sangat baik. Guru sudah meningkatkan kegiatan untuk memantau kedisiplinan siswa dan keterampilan dalam mengkondisikan kelas. Motivasi yang diberikan guru kepada siswa ketika proses pembelajaran dengan menggunakan model pembelajaran PBL dapat meningkatkan keaktifan siswa dalam belajar. Kegiatan diskusi kelompok pada pertemuan ini sudah sangat baik. Pada pertemuan ini, siswa terlihat lebih aktif dan antusias sehingga proses pembelajaran berjalan lebih menyenangkan.

Berdasarkan hasil yang telah diperoleh aktivitas guru pada siklus II menunjukan bahwa guru telah melaksanakan langkah-langkah pembelajaran dengan sangat baik.Sedangkan dari aktivitas pembelajaran siswa pada siklus II, keaktifan siswa dalam pembelajaran sangat baik. Hal ini menunjukkan bahwa siswa telah menunjukkan aktivitas yang lebih positif pada siklus II ketika diterapkan model pembelajaran PBL. Adanya peningkatan oleh guru dan siswa ini karena pada saat pelaksanaan kegiatan pembelajaran siklus II guru sudah melakukan perbaikan-perbaikan berdasarkan hasil refleksi pada siklus I. Antara lain dengan memberikan motivasi yang lebih, menjelaskan lebih rinci kepada siswa mengenai teknik lari yang benar serta memberikan bimbingan dengan merata dan menyeluruh pada siswa.
Penilaian siswa pada siklus I dan siklus II terdiri dari penilaian sikap, pengetahuan dan ketrampilan siswa sehingga didapatkan nilai akhir. Nilai sikap tersebut berdasarkan hasil sikap siswa ketika proses pembelajaran berlangsung. Aspek yang dinilai meliputi sportifitas, keaktifan, dan kedisiplinan. Pada siklus I, aspek yang sering muncul yaitu keaktifan, sedangkan pada siklus II semua aspek yaitu sportivitas, keaktifan, dan kedisiplinan sudah muncul. Penilaian ketrampilan diperoleh dari nilai optimum saat dilakukan praktek teknik gerak dasar lari. Nilai pengetahuan siswa berdasarkan pada perolehan nilai pada hasil tes pengetahuan.

Berdasarkan temuan pada siklus I dan siklus II terlihat bahwa penggunaan model pembelajaran PBL dalam pembelajaran PJOK materi teknik gerakan dasar lari pada siswa kelas IV SD telah dilaksanakan guru secara baik, dan penelitian dapat berjalan dengan lancar. Selain itu siswa juga semakin memahami penerapan model pembelajaran PBL, hal ini terlihat dari keantusiasan siswa saat mengikuti pembelajaran, sehingga berdampak pada meningkatnya hasil belajar siswa.

Temuan yang diperoleh dari hasil penelitian pada hasil belajar siswa menunjukan adanya peningkatan. Pada siklus I pertemuan 1 menunjukan ketuntasan siswa. Pada pertemuan 1 memperoleh persentase sebesar $18 \%$ dan pada pertemuan 2 memperoleh persentase sebesar $25 \%$. Hal ini menunjukan adanya peningkatan hasil belajar sebanyak 7\%. Secara umum hal ini belum dapat dikatakan tuntas karena belum ada $80 \%$ siswa yang tuntas belajar. Oleh karena itu hasil yang diperoleh pada siklus I diperbaiki pada siklus II. Hasil perbaikan pada siklus II menunjukan hasil bahwa ketuntasan belajar siswa pada pertemuan 1 memperoleh persentase sebesar $79 \%$ dan pada pertemuan 2 memperoleh persentase sebesar 93\%.

Hasil belajar siswa dalam pelaksanan siklus II diketahui hampir seluruh siswa mencapai KKM yang ditentukan. Hal ini menunjukkan adanya peningkatan jika dibandingkan dengan perolehan hasil pada siklus I. Peningkatan ini sebagai indikator bahwa penerapan model pembelajaran PBL dapat digunakan untuk meningkatkan hasil belajar PJOK pada Tema 9/Makanan Sehat dan Bergizi, Sub Tema 3/Kebiasaan Makananku, pembelajaran pada 
siswa kelas IV /A Sekolah Dasar Negeri Sentul 3 Kota Blitar semester II tahun 2015/2016.

\section{KESIMPULAN DAN SARAN}

\section{Kesimpulan}

Berdasarkan paparan data dan temuan penelitian serta pembahasan dapat dikemukakan beberapa kesimpulan. Penggunaan model pembelajaran PBL dalam pembelajaran PJOK materi teknik gerakan dasar lari pada siswa kelas IV SD telah dilaksanakan guru secara baik, dan penelitian dapat berjalan dengan lancar. Hal ini terjadi karena guru melakukan refleksi pada akhir siklus I, kemudian kekuranganya dilakukan perbaikan pada siklus II. Penerapan model pembelajaran PBL dapat meningkatkan hasil belajar PJOK materi lari. Guru mampu meningkatkan aktivitas belajar siswa, mendorong siswa untuk berusaha menerapkan pengetahuan mereka dengan kerja kelompok, berdiskusi, saling bekerjasama dalam menyelesaikan suatu masalah secara bersama.

\section{Saran}

Berdasarkan kesimpulan di atas disarankan bagi guru dalam meningkatkan hasil belajar siswa hendaknya menggunakan metode yang bervariasi dan menerapkan model pembelajaran sesuai dengan kegiatan pembelajaran yang berlangsung. Hal tersebut dapat membuat siswa menjadi lebih aktif dan bersemangat untuk mengikuti pembelajaran.
Guru dapat memberikan reward pada siswa agar lebih aktif dan tidak malu menjawab pertanyaan guru. Selain itu, guru bisa memberikan bimbingan secara merata baik secara kelompok maupun pada semua siswa.

\section{DAFTAR RUJUKAN}

Departemen Pendidikan Nasional. 2003. UndangUndang Nomor 20 Tahun 2003 Tentang Sistem Pendidikan Nasional. Jakarta: Depdiknas.

Dimyati dan Mudjiono. 2002. Belajar dan Pembelajaran. Jakarta: Rineka Cipta dan Depdikbud.

Faiq, M. 2014. Model Pembelajaran Project Based Learning dan Kurikulum 2013, (Online), (http:// penelitiantindakan kelas. blogspot. co.id /2014/05/model-pembelajaran-projectbased.html), diakses 25 April 2016.

Kemmis, S. dan Mc. Taggart, R. 1998. The Action Research Planner. Victoria: Dearcin University.

Kuntjojo, dkk. 2011. Modul Model-model Pembelajaran. Modul disajikan dalam Pendidikan dan Latihan Guru Profesional PSG Rayon Universitas Nusantara PGRI Kediri. Kediri: 2011.

Moleong, L. J. 2004. Metodologi Penelitian Kualitatif. Bandung: Remaja Rosdakarya.

Mulyasa, E. 2007. Menjadi Guru Profesional menciptakan Pembelajaran Kreatif dan Menyenangkan. Bandung: Rosdakarya 